\title{
"EFEKTIVITAS KOMUNIKASI PENYULUH PERTANIAN DALAM USAHATANI KEDELAIDI KECAMATAN RANTAU RASAU KABUPATEN TANJUNG JABUNG TIMUR"
}

\author{
Adelia ${ }^{1)}$, Ratnawati Siata ${ }^{2}$ )dan Tri Suratno ${ }^{2}$ ) \\ 1) Alumni Jurusan Agribisnis Program Studi Agribisnis Fakultas Pertanian Universitas Jambi \\ $\left.{ }^{2}\right)$ Staf Pengajar Jurusan Agribisnis Fakultas Pertanian Universitas Jambi \\ Email :Adelia_nam@yahoo.com
}

\begin{abstract}
ABSTRAK
Penelitian ini merupakan penelitian kuantitaif yang dilaksanakan langsung di Kecamatan Rantau Rasau Kabupaten Tanjung Jabung Timur karena merupakan wilayah yang paling potensial untuk pengembangan pertanian kedelai dan merupakan salah satu sentra produksi kedelai di Kabupaten Tanjung Jabung Timur Provinsi Jambi. Fokus penelitian adalah untuk mengetahui efektivitas komunikasi yang dilakukan oleh PPL dengan perilaku petani pada usahatani kedelai di Kecamatan Rantau Rasau KabupatenTanjung Jabung Timur.Objek pengamatannya adalah pada usahatani kedelai yang masih aktif menghasilkan produksi kedelai. Metode penarikan sampel dilakukan secara acak sederhana (Simple Random Sampling), yaitu setiap populasi memiliki kesempatan yang sama untuk dipilih sebagai sampel dengan cara mengambil sampel dari anggota populasi secara acak dalam anggota populasi tersebut. (Singarimbun dan Effendi,1995). Penelitian yang dilakukan efektif bahwa komunikasi yang dilakukan oleh penyuluh mejelaskan langkah-langkah komunikasi. Penelitian yang dilakukan ini memperjelas bahwa langkah-langkah yang dilakukan PPL dilihat dari perilaku petani yaitu pengetahuan yang dimiliki petani, Penilaian pengetahuan sikap dan keterampilan atau tindakan petani untuk menerapkan atau tidak dari petunjuk yang di komunikasikan penyuluh kepada petani kedelai. Sikap baik petani ternyata belum cukup untuk membantu mereka menyerap apa saja yang disampaikan oleh penyuluh dengan baik.Adapun unsur-unsur dalam komunikasi yaitu : sender, encoding, message, media, decoding, receiver, response, feedback, dan noise.

Kata kunci : Efektivitas Komunikasi, Usahatani Kedelai

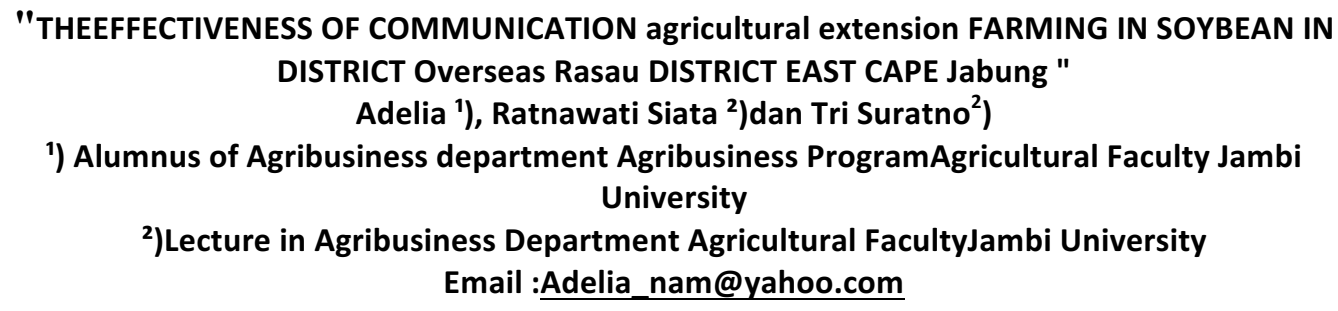

\section{ABSTRACT}

This research is a quantitative study that directly executed in the District Rasau Regency Tanjung Jabung Region East because it's an area with the most potential for expansion of soybean farming is one of the sentra and soybean production in the Eastern District of Tanjung Jabung Jambi Province. The focus of the study is to determine the effectiveness of the communication is done by PPL to the behavior of farmers in soybean farming in Sub Region East Jabung KabupatenTanjung Rasau. Object observation is in soybean farming is still actively producing soybean production. Methods for extraction of samples is done at random medium (Simple Random Sampling ), that each population has an equal chance of being selected as a sample by taking a sample from a random member of the population in the member population. ( Singarimbun and Effendi, 1995). Research conducted effective communication that is done by the instructor clearly explained the steps of communication. Research conducted clarify that these measures do PPL farmer behavior that is visible from the knowledge of farmers, on knowledge or attitudes and skills to farmers to apply or not the indication is communicated scout soybean farmers. The attitude of the farmers turned out to not be enough to help them absorb 
everything presented by the instructor well. As to the elements of communication that is: Sender , encoding,message,media,decoding,receiver,response,feedbacd,noise. .

Keywords: Communication Effectiveness, Soybean Farming

\section{PENDAHULUAN}

Pembangunan nasional merupakan serangkaian kegiatan yang mengupayakan pembangunan yang berkelanjutan dan merata di segala aspek kehidupan masyarakat, bangsa dan negara dalam mewujudkan tujuan nasional yang sebagaimana telah tercantum dalam pembukaan Undang-Undang Dasar 1945.Pembangunan nasional pada umumnya bertujuan dalam usaha peningkatan taraf hidup dan kesejahteraan seluruh rakyat Indonesia secara merata. Kedelai sebagai salah satu komoditas unggulan dari subsektor tanaman pangan, kini tidak lagi dianggap sebagai komoditas substitusi dari tanaman padi, melainkan secara utuh sebagai bagian yang sangat integral bagi kebutuhan akan pangan masyarakat, sehingga komoditi kedelai menjadi salah satu prioritas dalam pembangunan revitalisasi pertanian yang telah dicanangkan oleh pemerintah. Ketergantungan akan impor kedelai seharusnya dapat diatasi, hal ini mengingat akan potensi lahan yang cukup luas, sehingga apabila diusahakan oleh petani serta bantuan dari pemerintah tidak mustahil Indonesia untuk dapat berswasembada kedelai.

Perubahan posisi Indonesia menjadi negara importir kedelai merupakan permasalahan bagi agribisniskedelai lokal di Indonesia,yang bermuara pada produksi lokal kedelai yang jauh tertinggal dalam mengimbangi permintaan yang semakin tinggi. Dengan kata lain, hal ini terjadi karena produktivitas dan produksi kedelai lokal masih rendah. Kondisi ini diperburuk dengan semakin menurunnya luas panen kedelai.Tanpa perluasan areal tanam, upaya peningkatan produksi kedelai sulit dilakukan karena laju peningkatan produktivitas berjalan lambat, terlebih lagi bila harga sarana produksi tinggi dan harga produk rendah (Ariani, 2005).

Di indonesia pada tahun 2008 produksi kedelai di Indonesia sebanyak 775.710 tondengan luas panen $590.956 \mathrm{Ha}$. Sedangkan pada tahun 2010 ke 2011 terjadi kenaikan luas panen dari $660.823 \mathrm{Ha}$ menjadi $662.254 \mathrm{Ha}$. Sedangkan untuk hasil produksi kedelai dari tahun 2010 ke tahun 2011 terjadi penurunan sebanyak 55.745 ton. Sementara itu meski tidak signifikan, dari tahun 2008 ke tahun 2012 atau setiap tahunnya selalu terjadi kenaikan produktivitas kedelai.

Kurangnya produksi kedelai dalam negeri menyebabkan ketergantungan masyarakat Indonesia terhadap kedelai impor. Selain itu, banyak petani yang mulai meninggalkan usahatani kedelai karena dianggap kurang menguntungkan. Apalagi ditambah dengan maraknya penanaman tanamanperkebunan seperti kelapa sawit yang dianggap lebih menjamin kondisi ekonomi masyarakat. Hal ini mengakibatkan semakin menurunnya produksi kedelai di Indonesia dari tahun ke tahun, terutama sekali di Provinsi Jambi.Keadaan ini tentunya perlu mendapat perhatian dari pihak-pihak terkait terutama yang berhubungan dengan kegiatan usahatani kedelai. Pemerintah telah menggulirkan Program Bangkit Kedelai untuk mengatasi krisis yang berhubungan dengan pemenuhan kebutuhan kedelai,dalam upaya meningkatkan produksi kedelai nasional. Peran komunikasi yang dilakukan oleh Penyuluh Pertanian Lapangan (PPL) untuk meningkatkan wawasan petani mengenai pengembangan usaha tani kedelai menentukan keberhasilan upaya tersebut. PPL dalam melakukan penyuluhan pertanian harus mampu menjalin komunikasi yang efektif dan efisien dengan petani demi tercapai sasaran penyuluhan yang diharapkan. Dalam upaya untuk mencapai komunikasi yang efektif dan efisien, komunikasi yang dapat mencapai hasil sesuai harapan, maka dalam menyampaikan pesan kepada masyarakat hendaklah memiliki patokan-patokan, baik berdasarkan pengalaman, atau berdasarkan bahan bacaan dan juga pengalaman orang lain.

Penyuluh Pertanian Lapangan di Kecamatan Rantau Rasau memberikan gambaran mengenaibagaimana peningkatan produktivitas usahatani kedelai sehinggahasil usahatani tersebut bisa menguntungkan bagi petani. Selain itu, mereka juga memberikan gambaran bagaimana penanganan pasca panen kedelai sehingga bisa menghasilkan kedelai yang berkualitas dan bisa bersaing dengan kedelai impor.

Berdasarkan latar belakang dan permasalan yang dikemukakan, maka penelitian ini bertujuan untuk mengetahui efektivitas komunikasi penyuluh di Kecamatn Rantau Rasau, 
menganalisa efektivitas komunikasi penyuluh dilihat dari perilaku petani di kecamatan Rantau Rasau Kabupaten Tanjung Jabung Timur.

\section{METODE PENELITIAN}

Penelitian ini merupakan penelitian kuantitaif yang dilaksanakan langsung di Kecamatan Rantau Rasau Kabupaten Tanjung Jabung Timur karena merupakan wilayah yang paling potensial untuk pengembangan pertanian kedelai dan merupakan salah satu sentra produksi kedelai di Kabupaten Tanjung Jabung Timur Provinsi Jambi. Fokus penelitian adalah untuk mengetahui efektivitas komunikasi yang dilakukan oleh PPL dengan perilaku petani pada usahatani kedelai di Kecamatan Rantau Rasau KabupatenTanjung Jabung Timur.

Metode penarikan sampel yang digunakan adalah formula dari Taro Yamane Metode Slovin (1964) dalam Nazir (2005) adapun rumus Yamane yaitu dengan ketentuan apabila sampel lebih dari 100 orang maka diambil presisi 15\%-20\%, jika sampel 50-100 orang maka presisinya diambil $10 \%$ dan jika sampel kurang dari 50 orang maka sampel diambil semua. Adapun rumus penarikan sampel dapat digunakan rumus:

Dimana ;

$$
n=\frac{N}{N d^{2}+1}
$$

$$
\begin{array}{ll}
\mathrm{n} & =\text { Jumlah sampel } \\
\mathrm{N} & =\text { jumlah populasi } \\
\mathrm{d} & =\text { presisi yang ditetapkan }
\end{array}
$$

Dengan demikian, jumlah sampel yang akan diteliti adalah:

1. Jumlah sampel Desa Marga Mulia

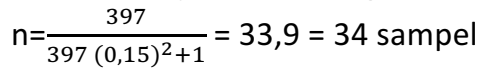

2. Jumlah sampel Desa Bandar Jaya

$$
\mathrm{n}=\frac{61}{61(0,15)^{2}+1}=26 \text { sampel }
$$

Dengan demikian dipilih dua Desa yaitu desa Marga Mulia dan Desa Bandar Jaya, dengan populasi yang tergabung dalam kelompok tani seperti pada Tabel 5 di bawah Ini :

Tabel 1. Jumlah Petani Kedelai di Kecamatan Rantau Rasau Kabupaten Tanjung Jabung Timur

\begin{tabular}{lll}
\hline Desa & \multicolumn{2}{c}{ Jumlah } \\
\cline { 2 - 3 } & Populasi Petani & Kelompok Tani \\
Marga Mulia & 397 & 13 \\
Bandar Jaya & 61 & 5 \\
\hline Jumlah & 458 & 18 \\
\hline
\end{tabular}

Pada Tabel 1 disebutkan untuk Desa Marga Mulia terdapat 397 petani yang tergabung dalam 13 kelompok tani, sedangkan di Desa Bandar Jaya terdapat 61 petani yang tergabung dalam 5 kelompok tani.

Metode analisis data pada dasarnya merupakan proses yang bertujuan untuk untuk menyederhanakan data yang diperoleh ke dalam bentuk yang lebih mudah dibaca dan di mengerti. Data yang diperoleh dari responden terlebih dahulu di sederhanakan secara tabulasi.Untuk mempelajari perilaku petani dan usahatani kedelai dianalisis secara deskriptif. Untuk mengetahui hubungan antara perilaku petani dengan usahatani kedelai dilakukan dengan analisis Chi-square (Siegel,1997)dengan kontingensi 2 x 2. Menurut sugiyono (2010), uji Chisquare digunakan untuk menguji hipotesis perbedaan dua kategor bila datanya berbentuk nominal dan sampelnya besar, setiap sampel terdapat beberapa kategori atau kelas.Perbedaan 
dalam sampel dapat digeneralisasikan dari perbedaan yang terjadi pada sampel maka dapat mencerminkan keadaan suatu populasi. Menurut Syamsul Bahry (2005), yaitu uji Chi-Square yang kontingensinya $2 \times 2$ menggunakan rumus sebagai berikut:

$$
\begin{aligned}
& X^{2}= \\
& (A+B)(C+D)(A+C)(B+D)
\end{aligned}
$$

Dimana $\mathrm{N}=$ jumlah frekuensi (sampel) hasil observasi

$$
X^{2}=\text { Jumlah rata - rata }
$$

\begin{tabular}{|c|c|c|c|}
\hline \multirow{2}{*}{$\begin{array}{l}\text { Komunikasi } \\
\text { antara } \\
\text { Penyuluh } \\
\text { dan Petani }\end{array}$} & \multicolumn{2}{|c|}{ Perilaku Petani dalam Kegiatan Usahatani Kedelai } & \multirow[t]{2}{*}{ Jumlah } \\
\hline & Tinggi (> rata-rata) & Rendah ( $\leq$ rata-rata) & \\
\hline Efektif & $A$ & B & $A+B$ \\
\hline Tidak efektif & C & $\mathrm{D}$ & $C+D$ \\
\hline Jumlah & $A+C$ & $B+D$ & $\mathrm{~N}$ \\
\hline
\end{tabular}

Tabel 2 .Metode Uji Chi-Square dengan kontingensi 2x2

Nilai $\left(x^{2}\right)$ pada tabel derajat bebas $(d b)=2$ padatingkat kepercayaan $95 \%$ adalah 5,99 . Dengan pengujiannya hitung, dibandingkan dengan tabel dengan keputusan sebagai berikut:

Terima Ho $=x^{2}$ hitung 5,99

Tolak $\mathrm{H} 1=x^{2}$ hitung $\quad 5,99$

Dimana:

$H_{0}=$ Perilaku petani dan PPL (pengetahuan, sikap dan tindakan) tidak mempengaruhi perilaku petani pada usahatani kedelai Kecamatan Rantau Rasau Kabupaten Tanjung Jabung Timur.

$H_{1}=$ Perilaku petani dan PPL (pengetahuan, sikap dan tindakan) mempengaruhi perilaku petani pada usahatani kedelai di Kecamatan rantau rasau Kecamatan Rantau Rasau Kabupaten Tanjung Jabung Timur.

Selanjutnya untuk mengukur derajat hubungan antara kedua variabel digunakan koefisien kontingensi dengan rumussebagai berikut:

$$
C_{\text {hit }}=\sqrt{\frac{x^{2}}{x^{2}+N}}
$$

Dimana:

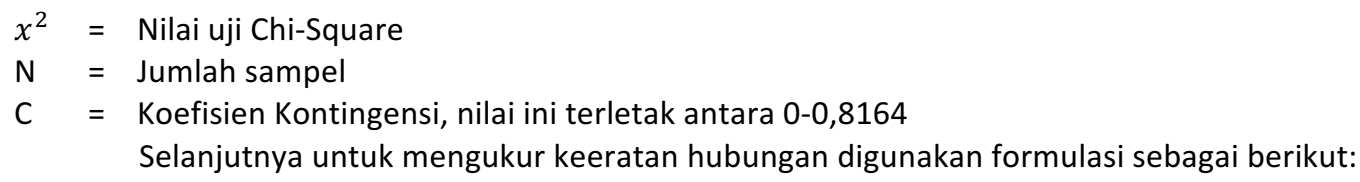

$C_{\text {maks }}=\sqrt{\frac{m-1}{m}}==\sqrt{\frac{3-1}{3}}=0,8164$

$$
r=\frac{C_{\text {hit }}}{C_{\text {maks }}} r=\frac{\sqrt{\frac{x^{2}}{x^{2}+N}}}{\frac{m-1}{m}}
$$

Keterangan :

$r=$ Koefisien keeratan hubungan

$x^{2}=$ Nilai uji Chi-Square 
$\mathrm{N} \quad=$ Jumlah sampel

$\mathrm{m}=$ Jumlah kolom / baris pada tabulasi silang

Dengan kategori :

a. Hubungan digolongkan lemah apabila nilai terletak antara 0-0,272

b. Hubungan digolongkan cukup kuat apabila nilai terletak antara 0,272-0,408

c. Hubungan digolongkan kuat apabila terletak antara 0,408-0,816

Dari kategori tersebut maka berhasil atau tidaknya ditentukan oleh sebesar $\propto=$ $5 \%$ selanjutnya untuk melihat adanya hubungan atau tidak maka digunakan formulasi yakni :

Dimana:

$$
t_{\text {hit }}=\sqrt{\frac{N-2}{1-(r)^{2}}}
$$

Ho ; $r=0$

$\mathrm{H} 1 ; \mathrm{r} \quad \mathrm{O}$

Dengan ketentuan/kaidah pengambilan keputusan:

Jika $t_{\text {hit }}\left\{\left(\leq t_{\text {tabel }}=(\alpha / 2=5 \% \mathrm{db}=\mathrm{N}-2)\right\}\right.$ Terima $H_{0}$

Jika $t_{\text {hit }}\left\{\left(\leq t_{\text {tabel }}=(\alpha / 2=5 \% \mathrm{db}=\mathrm{N}-2)\right\}\right.$ Terima $H_{1}$

$H_{0} \quad=$ Tidak terdapat efektivitas komunikasi PPL dengan perilaku petani pada usahatani kedelai diKecamatan Rantau Rasau Kabupaten Tanjung Jabung Timur.

$H_{1}=$ Terdapat efektivitas komunikasi PPL dengan perilaku petani usahatani kedelai di Kecamatan Rantau Rasau Kabupaten Tanjung Jabung Timur.

\section{HASIL DAN PEMBAHASAN}

\section{Karekteristik Petani}

Karekteristik merupakan cermin status sosial orang yang bersangkutan, dimana dia tinggal dan bermasyarakat.Status sosial sangat mempengaruhi individu seseorang dalam pengambilan keputusan. Oleh karena itu, jika status sosial seseorang dianggap baik dalm suatu masyarakat maka biasanya orang tersebut akan diakui dalam lingkungannya. Identitas petani sampel dalam penelitian ini adalah identitas petani yang mengusahakan tanaman kedelai di Kecamatan Rantau Rasau Kabupaten Tanjung Jabung Timur meliputi: Nama, Umur, Pendidikan, Jumlah Anggota Keluarga, Luas lahan, lama berusahatani.

\section{Umur Responden}

Menurut Hernanto (1998), pada umumnya petani yang berumur lebih muda dan sehat memiliki kemampuan fisik yang lebih cepat menerima hal-hal baru yang dianjurkan, hal ini disebabkan karena petani yang berusia muda lebih berani mengambil resiko. Petani yang masih muda biasanya masih kurang memiliki pengalaman, untuk mengurangi kekurangan tersebut petani dituntut lebih dinamis, sehingga petani mendapatkan pengalaman baru yang berharga bagi perkembangan hidupnya di masa yang akan datang.untuk lebih jelasnya megenai distribusi petani berdasarkan umur didaerah peneliti dapat dilihat pada Tabel 3 dibawah ini.

Tabel 3. Distribusi Responden Berdasarkan Kelompok Umur di Desa Marga Mulia dan Bandar Jaya di Kecamatan Rantau Rasau Kabupaten Tanjung Jabung Timur Tahun 2014

\begin{tabular}{cccc}
\hline NO. & $\begin{array}{c}\text { Umur Petani } \\
\text { (Tahun) }\end{array}$ & Jumlah & Persentase \\
& (Orang) & (\%) \\
\hline
\end{tabular}




\begin{tabular}{lccc}
\hline 1. & $25-30$ & 10 & 16.7 \\
2. & $31-35$ & 9 & 15 \\
3. & $36-40$ & 10 & 16.7 \\
4. & $41-45$ & 10 & 16.7 \\
5. & $46-50$ & 9 & 15 \\
6. & $51-55$ & 5 & 8.3 \\
7. & $56-60$ & 6 & 10 \\
8. & $\geq 60$ & 1 & 1.6 \\
\hline & Jumlah & $\mathbf{6 0}$ & $\mathbf{1 0 0}$ \\
\hline
\end{tabular}

Tabel 3 menunjukkan bahwa keadaan umur petani responden sebagian besar $15 \%$ berada pada kelompok umur 31-35 tahun.Petani responden yang memiliki umur produktif di daerah penelitian sebagian besar merupakan kelompok umur produktif.menurut Vacca dan walker dalam Mardikanto (1993),mengatakan bahwa selaras dengan bertambahnya umur seseorang akan memupuk pengalaman-pengalamannya yang merupakan sumber daya yang sangat berguna bagi kesiapannya untuk belajar lebih lanjut. Selanjutnya,diperjelas oleh Hernanto (1998),bahwa ada kecenderungan petani yang semakin tua,pertimbangan dan pengambilan keputusan lebih lama dibandingkan yang muda. Sebaliknya petani yang berusia lebih muda memiliki kemampuan bekerja yang lebih produktif dan lebih respon terhadap introduksi teknologi maju.

\section{Tingkat Pendidikan}

Pendidikan dapat dijadikan salah satu faktor terjadinya perbedaan pola pikir petani. Hal ini akhirnya akan berkaitan dengan perilaku mereka terhadap inovasi yang disampaikan kepada mereka. Semakin tinggi tingkat pendidikan petani, maka pola pikir mereka dapat lebih maju sehingga lebih mudah terbuka terhadap suatu perubahan atau inovasi yang diberikan kepada mereka.

Menurut Hernanto (1998), keterbatasan tingkat pendidikan akan mempengaruhi cara berpikir menerima, ataupun menolak hal-hal yang baru. Pendidikan yang dimaksud dalam penelitian ini adalah jenjang pendidikan formal yang pernah diikuti petani responden.Untuk lebih jelasnya tingkat pendidikan petani responden didaerah penelitian dapat dilihat pada Tabel 4.

Tabel 4. Responden Berdasarkan Tingkat Pendidikan Di Desa Marga Mulia dan Bandar Jaya di Kecamatan Rantau Rasau Kabupaten Tanjung Jabung Timur Tahun 2014

\begin{tabular}{clcc}
\hline NO & \multicolumn{1}{c}{ TINGKAT PENDIDIKAN } & $\begin{array}{c}\text { JUMLAH } \\
\text { (ORANG) }\end{array}$ & $\begin{array}{c}\text { PERSENTASE } \\
\text { (\%) }\end{array}$ \\
\hline 1 & Tidak Sekolah & 2 & 3,3 \\
2 & Tamat Sekolah Dasar / Sederajat & 19 & 31,7 \\
3 & Tamat SLTP / Sederajat & 14 & 23,4 \\
4 & Tamat SMA / Sederajat & 25 & 41,6 \\
\hline & JUMLAH & $\mathbf{6 0}$ & $\mathbf{1 0 0}$ \\
\hline
\end{tabular}

Tabel 4 menunjukkan bahwa tingkat pendidikan petani responden pada usahatani kedelai bervariasi.Petani banyak yang berpendidikan rendah, hal ini terlihat bahwa mayoritas petani hanya berpendidikan Sekolah Dasar (SD). Dimana jumlah petani yang tamat SMA memiliki jumlah terbesar yaitu sebanyak 41,6\%. Dikatakan bahwa semakin tinggi tingkat pendidikan petani tentunya akan memiliki wawasan pemikiran yang relatif luas dan bertindak lebih selektif dalam mengembangkan usahatani kedelai. Sehingga akan mempengaruhi perilaku dan pola pikir mereka.

\section{Jumlah Anggota Keluarga}

Jumlah anggota keluarga berkaitan dengan tingkat kepuasan seseorang dalam bekerja, produksi dan pemenuhan kebutuhan.Jumlah tanggungan keluarga yang dimaksud adalah anggota 
keluarga atau semua orang yang tinggal dalam satu rumah ataupun diluar rumah yang menjadi tanggungan kepala keluarga.Anggota keluarga terdiri dari suami, isteri, anak-anak, keluarga yang menjadi tanggunggan kepala keluarga.

Dalam penelitian ini jumlah anggota keluarga responden bervariasi antara $2 \mathrm{~s} / \mathrm{d} 9$ anggota keluarga yang menjadi tanggungan responden.

Tabel 5. Responden berdasarkan Jumlah Anggota Keluarga Sampel Petani Kedelai Kecamatan Rantau Rasau Kabupaten Tanjung Jabung Timur

\begin{tabular}{cccc}
\hline No & $\begin{array}{c}\text { Jumlah Anggota } \\
\text { Keluarga }\end{array}$ & Jumlah KK & Persentase (\%) \\
\hline 1. & $2-3$ & 20 & 33.4 \\
2. & $4-5$ & 29 & 48.3 \\
3. & $6-7$ & 9 & 15 \\
4. & $8-9$ & 2 & 3.3 \\
\hline & Jumlah & $\mathbf{6 0}$ & $\mathbf{1 0 0}$ \\
\hline
\end{tabular}

Tabel 5 menjelaskan bahwa hampir setengah dari responden tepatnya 48,3\% yang memiliki tanggungan keluaarga yang harus mereka nafkahi berkisar 4 atau 5 orang,dan 33,4\% memiliki 2 atau 3 orang tanggungan,selebihnya terbagi untuk petani yang memiliki julah keluarga diatas 5 orang.

\section{Luas Lahan}

Pada umumnya, akan lebih memiliki semangat kerja dan motivasi kerja yang tinggi saat memiliki lahan yang luar. Lahan merupakan salah satu faktor produksi dalam berusahatani kedelai.Luas lahan yang dimiliki petani dapat mempengaruhi produksi, semakin luas lahan yang dimiliki maka semakin banyak produksi yang diperoleh. Untuk lebih jelas luas lahan yang dimiliki responden dapat dilihat pada Tabel 6 dibawah ini :

Tabel 6. Responden Berdasarkan Luas Lahan di Desa Marga Mulia dan Bandar Jaya di Kecamatan Rantau Rasau Kabupaten Tanjung Jabung Timur Tahun 2013

\begin{tabular}{cccc}
\hline No & Luas Lahan (Ha) & Jumlah (orang) & Persentase (\%) \\
\hline 1. & $1-1,5$ & 30 & 50 \\
2. & $2-2,5$ & 22 & 36.6 \\
3. & $3-3,5$ & 4 & 6.7 \\
4. & $4-5$ & 4 & 6.7 \\
\hline & Jumlah & $\mathbf{6 0}$ & $\mathbf{1 0 0}$ \\
\hline
\end{tabular}

Tabel 6 menunjukkan bahwa sebagian besar luas lahan petani 4-5 Ha sebesar $6.7 \%$

\section{Pengalaman Berusahatani}

Pengalaman seseorang akan dapat dijadikan tolak ukur untuk pengembangan dimasa yang akan datang. Semakin lama berusahatani, maka semakin berpengalaman berusahatani. Petani dengan pengalaman berusahatani yang cukup lama sangat hati-hati dalam menerima inovasi yang dianggap baru, karena petani mempertimbangkan resiko kegagalan bila menerapkan inovasi tersebut. Sejalan dengan pendapat Mosher (1986), dari tahun ketahun akan bertambah pengetahuan petani meskipun tidak banyak.

Keadaan lama bekerja dari responden dalam berusahatani kedelai dapat dilihat pada Tabel 7 dibawah ini. 
Tabel 7.Responden Berdasarkan Pengalaman Berusahatani di Desa Marga Mulia dan Bandar Jaya di Kecamatan Rantau Rasau Kabupaten Tanjung Jabung Timur tahun 2014

\begin{tabular}{cccc}
\hline No & Lama Berusaha Tani (Tahun) & Jumlah (Orang) & Persentase (\%) \\
\hline 1. & $1-3$ & 7 & 11.7 \\
2. & $4-5$ & 26 & 43.3 \\
3. & $6-7$ & 27 & 45 \\
\hline & Jumlah & $\mathbf{6 0}$ & $\mathbf{1 0 0}$ \\
\hline
\end{tabular}

Tabel 7 menunjukkan bahwa sebagian besar $45 \%$ dari petani lama berusahatani kedelai sekitar 6-7 tahun.

\section{Perilaku Petani dalam Usahatani Kedelai}

Proses perubahan perilaku (pengetahuan, sikap, dan keterampilan) dikalangan masyarkat (petani) bertujuan agar mereka tahu, mau dan mampu melaksanakan perubahanperubahan dalam usahataninya demi tercapainya peningkatan produksi, pendapatan atau keuntungan dan perbaikan kesejahteraan keluarga/masyarakat yang ingin dicapai melalui pembangunan pertanian. Perilaku merupakan suatu respon organism atau seseorang terhadap rangsangan dari luar terhadap subjek.Respon ini dapat bersifat pasif (tanpa rangsangan) dan bersifat aktif (dengan tindakan). Perilaku petani dalam usahatani kedelai dapat dilihat dari tiga komponen, yaitu kognitif (pengetahuan) afektif (sikap) dan psikomotor (keterampilan).

\section{Pengetahuan}

Kognitif adalah aspek perilaku yang berkenaan dengan pengetahuan yang merupakan hasil tahu yang terjadi setelah seseorang melakukan pengindraan terhadap suatu objek tertentu.Pengetahuan merupakan domain yang sangat penting untuk terbentuknya tindakan seseorang. Petani akan mengetahui langkah-langkah budidaya tanaman kedelai mulai dari syarat tumbuh, jenis pupuk yang akan digunakan, jenis hama dan penyakit yang akan menyerang serta jenis varietas kedelai yang cocok untuk ditanam. Pengetahuan juga mengetahui modal yang diperlukan dalam berusahatani kedelai.

Berikut adalah gambaran efektivitas komunikasi PPL dalam perilaku petani pada usahatani kedelai dilihat dari aspek kognitif (pengetahuan) yang disajikan pada pada Tabel 8 dibawah ini.

Tabel 8. Skor Pengetahuan Petani dalam Efektivitas Komunikasi PPL dalam Perilaku Petani pada Usahatani Kedelai di Desa Marga Mulia dan Bandar Jaya di Kecamatan Rantau Rasau Kabupaten Tanjung Jabung Timur Tahun 2014

\begin{tabular}{cccc}
\hline SKOR & KATEGORI & FREKUENSI & $\begin{array}{c}\text { PERSENTASE } \\
\text { (\%) }\end{array}$ \\
\hline $51-75$ & Efektif & 40 & 66,7 \\
$50-26$ & Kurang Efektif & 20 & 33,3 \\
\hline
\end{tabular}

Tabel 8 Memperlihatkan bahwa sebagian besar ( 66,7 \%) dari petani memiliki tingkat pengetahuan terhadap Efektivitas Komunikasi Penyuluh dalam perilaku petani dalam usahatani kedelai.Pengetahuan didapatkan dari pertemuan rutin Kelompok Tani yang dilakukan setiap hari sabtu yang dikoordinir oleh Penyuluh Lapangan dan diskusi yang dilakukan dalam setiap pertemuan,serta aplikasi dilapangan yang laksanakan oleh petani dan PPL. Hal ini mengindikasikan bahwa antusias sebagian petani untuk mengetahui hal yang berkaitan untuk peningkatan hasil produksi kedelai agar meningkatnya kesejahteraan petani.

Sikap

Afektif berkaitan erat dengan perasaan atau penelian individu terhadap objek atau subjek yang sejalan dengan pengetahuan. Berikut adalah gambaran efektivitas komunikasi PPL dalam perilaku petani pada ushatani kedelai dilihat dari aspek sikapafektif(penilian emosional) responden terhadap usahatani kedelai yang disajikan pada Tabel 9. 
Tabel 9. Skor Sikap Petani dalam Efektivitas Komunikasi PPL dalam Perilaku Petani pada Usahatani Kedelai di Desa Marga Mulia dan Bandar Jaya di Kecamatan Rantau Rasau Kabupaten Tanjung Jabung Timur Tahun 2014

\begin{tabular}{cccc}
\hline SKOR & KATEGORI & FREKUENSI & $\begin{array}{c}\text { PERSENTASE } \\
\text { (\%) }\end{array}$ \\
\hline $65-71$ & Efektif & 41 & 68,3 \\
$56-64$ & Kurang Efektif & 19 & 31,7 \\
\hline
\end{tabular}

Tabel 9 menunjukkan bahwa sebagian besar petani (68,3 \%) mendukung terhadap Komunikkasi Penyuluhan yang dilaksanakan, karena petani di desa Marga Mulia dan Bandar jaya memiliki sifatdan pemikiran yang terbuka untuk dan mau berusaha untuk maju dan modern dalam berusahatani dengan maksud pencapaian hasil produksi yang maksimal agar tercapainya kesejahteraan kehidupan petani tersebut.

\section{Keterampilan}

Psikomotorberkaitan dengan kemampuan bertindak setelah seseorang menerima pengalaman belajar terhadap suatu subjek, dapat aktif/positif atau positif/negatif dengan kata lain melaksanakan efektivitas komunikasi PPL dalam perilaku petani pada usahatani kedelai. Berikut adalah gambaran efektivitas komunikasi PPL dalam perilaku petani pada usahatani kedelai dilihat dari aspek psikomotor (keterampilan) responden terhadap usahatani kedelai yang sajikan dalam Tabel 10.

Tabel 10. Skor Keterampilan Petani dalam Efektivitas Komunikasi PPL dalam Perilaku Petani pada Usahatani Kedelai di Desa Marga Mulia dan Bandar Jaya di Kecamatan Rantau Rasau Kabupaten Tanjung Jabung Timur Tahun 2014

\begin{tabular}{cccc}
\hline SKOR & KATEGORI & FREKUENSI & $\begin{array}{c}\text { PERSENTASE } \\
\text { (\%) }\end{array}$ \\
\hline $59-75$ & Efektif & 40 & 66,7 \\
$43-58$ & Kurang Efektif & 20 & 33,3 \\
\hline Tabel 10 menunjukkan bahwa sebagian besar dari petani $(66,7 \%)$ cukup terampil dalam
\end{tabular}
artian mereka berperilaku aktif menerapkan sistem yang di bekali oleh PPL sehingga efektivitas komunikasi efektif.

3. Efektivitas Komunikasi Penyuluh dalam Usahatani Kedelai Hubungan Pengetahuan dengan Efektivitas Komunikasi Penyuluh dalam Perilaku Petani Pada Usahatani Kedelai

Berikut ini adalah gambaran hubungan Pengetahuan dengan efektivitas komunikasi penyuluh dalam usahatani kedelai responden yang disajikan pada Tabel 11 dibawah ini :

Tabel 11. Kontingensi Pengetahuan Responden tenntang Efektivitas Komunikasi Penyuluh dalam Usahatani Kedelai di Desa Marga Mulia dan Bandar Jaya di Kecamatan Rantau Rasau Kabupaten Tanjung Jabung Timur Tahun 2014

\begin{tabular}{lccc}
\hline \multicolumn{1}{c}{$\begin{array}{c}\text { Komunikasi antara } \\
\text { Penyuluh dan Petani }\end{array}$} & \multicolumn{2}{c}{$\begin{array}{c}\text { Pengetahuan Petani dalam Kegiatan } \\
\text { Usahatani Kedelai }\end{array}$} & Jumlah \\
\cline { 2 - 4 } & \multicolumn{3}{c}{ Rendah ( $\leq$ rata-rata) } \\
Efektif & 23 & 17 & 40 \\
Tidak efektif & 9 & 11 & 20 \\
\hline Jumlah & $\mathbf{3 2}$ & $\mathbf{2 8}$ & $\mathbf{6 0}$ \\
\hline
\end{tabular}

Tabel 11 memperlihatkan bahwa (66.7\%) petani memahami efektivitas komunikasi Penyuluh Lapangan dalam usahatani kedelai, artinya mengindikasikan bahwa petani di daerah penelitian telah mengenali efektivitas komunikasi penyuluh yang disampaikan. Berdasarkan uji statistic non parametrik dengan menggunakan uji square diperoleh nilai $X^{2}$ sebesar 0,837 dengan 
nilai $X^{2}$ tabel $(\alpha=5 \% \mathrm{db}=2)=5,991$ karena $X^{2}$ hitung $=0,837<X^{2}$ tabel maka diputuskan terima Ho dan tolak H1,artinya perilaku petani dan PPL tidak begitu besar mempengaruhi perilaku pengethuan petani pada usaha tani Kedelai Kecamatan Rantau Rasau Kabupaten Tanjung Jabung Timur.Derajat Kontingensi pengetahuan petani tentang efektivitas komunikasi penyuluh adalah Chit $=0.1172$ dan Cmaks $=0.8164$.

Artinya derajat kecendeerungan pengetahuan petani terhadap efektivitas komunikasi penyuluh tergolong lemah karena Chit berada di antara $0-0,272$.

Sedangkan pengukuran derajat korelasi antara perbedaan tingkat pengetahuan dalan efektivitas komunikasi penyuluh diperoleh $r=0.143$. Hasil pengujian tergahad koofisien $r$ diperoleh Thit $=$ 1,442. Karena Thit 1,442 tabel $(\alpha / 2=5 \% \mathrm{db}=\mathrm{N}-2)=1,671$, maka tolak Ho (terima $\mathrm{H} 1$ ) artinya perbedaan tingkat pengetahuan berhubungan erat dengan Efektivitas komunikasi ppenyuluh pada usahatani kedelai di Desa Marga Mulia dan Bandar Jaya Kecamatan Rantau Rasau Kabupaten Tanjung Jabung Timur.

Menurut Hernanto (1998), pengetahuan petani bisa dikaitkan dengan tingkat pendidikan petani yang akan mempengaruhi cara berpikir menerima ataupun menolak hal-hal baru. Pendidikan yang dimaksud dalam penelitian ini adalah jenjang pendidikan formal yang pernah diikuti petani sesuai dengan pengetahuan petani pada umumnya.

\section{Hubungan Sikap dengan Efektivitas Komunikasi Penyuluh dalam Perilaku Petani Pada Usahatani Kedelai \\ Menurut Notoatmodjo (2010), sikapmerupakan suatu penilian petani terhadap pengetahuan yang diniilai terhadap efektivitas komunikasi yang dilakukan penyuluh pada usahatani kedelai. Sikap petani dalam menerima komunikasi penyuluh yang dinilai positif, sebab akan berpengaruh terhdap hasil yang akan diperolehnya. Berikut ini adalah gambaran hubungan afektif petani dengan efektivitas penyuluh pada usahatani kedelai dapat dilihat pada Tabel 12berikut :}

Tabel 12. Kontingensi Sikap Responden tenntang Efektivitas Komunikasi Penyuluh dalam Usahatani Kedelai di Desa Marga Mulia dan Bandar Jaya di Kecamatan Rantau Rasau Kabupaten Tanjung Jabung Timur Tahun 2014

\begin{tabular}{lccc}
\hline $\begin{array}{c}\text { Komunikasi } \\
\text { antara } \\
\begin{array}{c}\text { Penyuluh } \\
\text { dan Petani }\end{array}\end{array}$ & \multicolumn{2}{c}{$\begin{array}{c}\text { Pengetahuan } \\
\text { Usahatani Kedelai }\end{array}$} & Jumlah \\
\cline { 2 - 4 } & Tinggi (> rata-rata) & Rendah ( rata-rata) & \\
Efektif & 3 & 38 & 41 \\
Tidak efektif & 9 & 10 & 19 \\
\hline Jumlah & 12 & 48 & 60 \\
\hline
\end{tabular}

Tabel 12 memperlihatkan bahwa bagaiman sikap petani degan efektivitas komunikasi penyuluh pada usahatani kedelai di Desa Marga Mulia dan Bandar Jaya di Kecamatan Rantau Rasau ada kecenderungan sikap petani sangat mendukung komunikasi yang diterapkan oleh PPL setempat.

Berdasarkan uji statistic non parametrik dengan menggunakan uji square diperoleh nilai $X^{2}$ sebesar 13,0166 dengan nilai $X^{2}$ tabel $(\alpha=5 \% d b=2)=5,991$, karena $X^{2}$ hitung $=13,0166>X^{2}$ tabel maka diputuskan terima $\mathrm{H} 1$ dan tolak Ho,artinya perilaku petani dan PPL Sangat besar mempengaruhi Sikap petani pada usaha tani Kedelai Kecamatan Rantau Rasau Kabupaten Tanjung Jabung Timur.Derajat Kontingensi Sikap petani tentang efektivitas komunikasi penyuluh adalah Chit $=0,4222$ dan Cmaks $=0.8164$.

Artinya derajat kecenderungan Sikap menerima petani terhadap efektivitas komunikasi penyuluh tergolong kuat karena Chit berada di antara 0,408 - 0,816. Sedangkan pengukuran derajat korelasi antara perbedaan Sikap dalam efektivitas komunikasi penyuluh diperoleh $r=0.5174$ 
.Hasil pengujian terhadap koofisien $r$ diperoleh Thit $=12.466$, karena Thit $12.466>$ tabel $(\alpha / 2=5 \%$ $\mathrm{db}=\mathrm{N}-2$ ) $=1,671$ maka tolak Ho (terima $\mathrm{H} 1$ ) artinya Sikap baik dan terbuka yang ditunjukan petani terhadap komunikasi yang diberikan penyuluh pada usahatani kedelai di Desa Marga Mulia dan Bandar Jaya Kecamatan Rantau Rasau Kabupaten Tanjung Jabung Timur.

\section{Hubungan Keterampilan dengan Efektivitas Komunikasi Penyuluh dalam Perilaku Petani Pada Usahatani Kedelai}

Psikomotor merupakan aspek perilaku mengenai respon petani terhadap efektivitas komunikasi penyuluh pada usahatani kedelai yaitu aktif/positif (dengan tindakan). Menurut petani dalam efektivitas komunikasi penyuluh ini cukup menguntungkan karena hasil produksi cukup digunakan kembali untuk memenuhi kebutuhan akan modal dalam berusahatani kedelai pada masa tanam berikutnya. Sebagian petani juga menyatakan hal demikian.Berikut ini adalah gambaran hubungan petani dengan efektivitas komunikasi penyuluh pada usahatani kedelai.

Tabel 13 memperilahatkan bahwa bagaiman hubungan keterampilan petani dengan efektivitas komunikasi penyuluh pada usahatani kedelai didaerah penelitian, yaitu ada kecenderungan bahwa kererampilan petani sangat terampil maka efektivitas komunikasi penyuluh pada usahatani kedelai akan baik atau akan tinggi dan sebaliknya jika efektivitas komunikasi penyuluh pada usahatani kedelai rendah maka keterampilan akan kurang terampil.

Tabel 13. Kontingensi Keterampilan Responden tenntang Efektivitas Komunikasi Penyuluh dalam Usahatani Kedelai di Desa Marga Mulia dan Bandar Jaya di Kecamatan Rantau Rasau Kabupaten Tanjung Jabung Timur Tahun 2014

\begin{tabular}{cccc}
\hline $\begin{array}{c}\text { Komunikasi } \\
\text { antara Penyuluh } \\
\text { dan Petani }\end{array}$ & \multicolumn{2}{c}{$\begin{array}{c}\text { Pengetahuan Petani dalam Kegiatan } \\
\text { Usahatani Kedelai }\end{array}$} \\
\cline { 2 - 4 } Efektif & Tinggi (> rata-rata) & Rendah ( & Jata-rata) \\
Tidak efektif & 26 & 4 & 40 \\
\hline Jumlah & 16 & 28 & 20 \\
\hline
\end{tabular}

Tabel 13 memperlihatkan bahwa bagaiman Keterampilan petani yang didapatkan dari komunikasi penyuluh dalam usahatani kedelai di Desa Marga Mulia dan Bandar Jaya di Kecamatan Rantau Rasau sedikit banyak bertambah baik dan mendukung komunikasi yang diterapkan oleh PPL setempat.

Berdasarkan uji statistic non parametrik dengan menggunakan uji square diperoleh nilai $X^{2}$ sebesar 1,428 dengan nilai $X^{2}$ tabel $(\alpha=5 \% d b=2)=5,991$ karena $X^{2}$ hitung $=1,428<X^{2}$ tabel maka diputuskan terima Ho,artinyaperilaku petani dan PPL kurang mempengaruhi keterampilan petani pada usaha tani Kedelai Kecamatan Rantau Rasau Kabupaten Tanjung Jabung Timur.Derajat Kontingensi keterampilan petani tentang efektivitas komunikasi penyuluh adalah Chit = 0,152 dan Cmaks =0.8164.

Artinya derajat Keterampilan petani terhadap efektivitas komunikasi penyuluh tergolong lemah karena Chit berada di antara 0-0,272. Pengukuran derajat korelasi antara perbedaan Sikap dalam efektivitas komunikasi penyuluh diperoleh $r=0.152$. Hasil pengujian tergahad koofisien $r$ diperoleh Thit $=1.178$, Karena Thit $1.178<$ tabel $(\alpha / 2=5 \% \mathrm{db}=\mathrm{N}-2)=1,671$, maka keputusannya terima Ho artinya perbedaan tingkat keterampilan belum begitu berpengaruh Efektivitas komunikasi penyuluh pada usahatani kedelai di Desa Marga Mulia dan Bandar Jaya Kecamatan Rantau Rasau Kabupaten Tanjung Jabung Timur.

Menurut Notoatmodjo (2010), keterampilan petani berkaitan dengan kemampuan bertindak setelah seseorang menerima pengalaman belajar terhadap suatu subjek, dapat aktif/positif atau positif/negatif dengan kata lain melaksanakan efektivitas komunikasi PPL dalam perilaku petani pada usahatani kedelai. Berikut adalah gambaran efektivitas komunikasi PPL 
dalam perilaku petani pada usahatani kedelai dilihat dari aspek psikomotor (keterampilan) responden terhadap usahatani kedelai.

\section{KESIMPULAN}

Dari uraian diatas maka dapat disimpulkan bahwa efektifitas komunikasi yang dilakukan penyuluh telah efektif.Hal ini dapat dari perilaku petani dilihat dari pengetahuan, sikap dan ketarampilan petani menerapakn efektivitas komunikasi yang dianjurkan oleh PPL dapat terlaksana dengan baik.Di daerah penelitian juga terdapat hubungan yang nyata antara efektivitas komunikasi PPL dalam perilaku petani pada usahatani kedelai di Kecamatan Rantau Rasau Kabupaten Tanjung Jabung Timur.

\section{UCAPAN TERIMA KASIH}

Terima kasih kepada Bapak Camat Kecamatan Rantau Rasau, Kepala BP3K Kecamatan Rantau Rasau, serta masyarakat yang bersedia memberikan keterangan untuk keperluan data penelitian.Terima kasih kepada Staf Dinas Badan Pusat Statistik Provinsi Jambi yang telah memberikan literature berupa bantuan data skunder.

\section{DAFTAR PUSTAKA}

Ariani, M., 2005.Penawaran dan Permintaan Kacang-kacangan dan Umbi-umbian di Indonesia.SOCA 5(1): 48-56.

Bahri, Syamsuri. 2011. Faktor-Faktor yang Mempengaruhi Penyuluh dalam Meningkatkan Produksi Kedelai di Kecamatan Rantau rasau Kabupaten Tanjung Jabung Timur.

BP3K,Kecamatan Rantau Rasau. Kelompok Tani Jumlah Anggota dan Luas Usahatani Kedelai di Desa Kecamatan rantau rasauTahun 2012.Jambi.

Hernanto, F. 1996. Ilmu Usahatani. Penerbit Swadaya. Jakarta

Mardikanto, Totok. 1993. Penyuluhan Pembangunan Pertanian. Sebelas Maret University Press. Surakarta.

Notoatmodjo, Soekidjo. 2010. Ilmu Perilaku Kesehatan. Renika Cipta. Jakarta.

Singarimbun, M dan Effendi, 1995. Metode Penelitian Survei.LP3ES. Jakarta.

Sugiyono, 2011.Metode penelitian kuantitatif, kualitatif, dan R\&D. Alfbeta. Bandung. 